\title{
KEKUATAN HUKUM SURAT KETERANGAN AHLI WARIS BAGI ANAK LUAR KAWIN DARI PERKAWINAN TIDAK TERCATAT
}

\author{
Tengku Erwinsyahbana \\ Fakultas Hukum Universitas Muhammadiyah Sumatera Utara \\ Jalan Mukhtar Basri No. 223 Medan, Sumatera Utara \\ tengkuerwins@umsu.ac.id
}

\author{
Harmita \\ Program Magister Kenotariatan Universitas Muhammadiyah Sumatera Utara \\ Jalan Denai_No. 217 Medan, Sumatera Utara \\ hharmita870@gmail.com
}

\begin{abstract}
Based on the Decision of the Constitutional Court Number 46/PUU-VIII/ 2010, a child born from an unregistered marriage may have a civil relationship with his biological father, so as to remain inherited, and to obtain legal certainty as an heir the name of the uregistered marrieage born child should mentioned as the heir. This fact is interesting to be examined and it aims to obtain answers of the legal strength of the heirs' certificate of unrecorded marriage. This research type is juridical normative with legislation approach through the descriptivequalitative method. The results of the study indicate that in order to obtain legal certainty, it is supposedly that the certificate of inheritance contains the name of the unrecorded marriage born child. But, this is can't be done, because there is no legislation determines that the child's name from unregistered marriage could be contained in the letter. So, with no legislation, the certificate of inheritance containing the name of the unregistered marriage child has no legal power, and therefore it is recommended that the government immediately make a regulation concerning the inheritance certificate for the child from unregistered marriage, so it could be clear and fixed.
\end{abstract}

Keywords: Heir; Outer Child Marriage; Certificate of Heirs

\begin{abstract}
Abstrak
Berdasarkan Putusan Mahkamah Konstitusi Nomor 46/PUU-VIII/2010, anak yang lahir dari perkawinan tidak tercatat dapat mempunyai hubungan perdata dengan bapak biologisnya, sehingga tetap berhak mendapat warisan, dan untuk memperoleh kepastian hukum sebagai ahli waris, maka dalam surat keterangan ahli waris seharusnya nama anak luar kawin disebutkan sebagai ahli waris. Fakta ini menarik untuk diteliti yang bertujuan untuk memperoleh jawaban yang terkait dengan kekuatan hukum surat keterangan ahli waris bagi anak luar kawin dari perkawinan tidak tercatat. Jenis penelitian ini adalah yuridis normatif dengan pendekatan perundang-undangan, dan sifatnya deskriptif. Sumber data yang digunakan dalam penelitian adalah data sekunder yang terdiri dari bahan hukum primer, sekunder dan tersier, sedangkan alat pengumpul data yang digunakan adalah studi dokumen. Data yang terkumpul dianalisis secara yuridis kualitatif. Hasil penelitian menunjukkan bahwa untuk mendapat kepastian hukum, seharusnya dalam surat keterangan
\end{abstract}


ahli waris memuat nama anak dari perkawinan tidak tercatat, tetapi hal ini tidak dapat dilakukan, karena tidak ada peraturan perundang-undangan yang menentukan bahwa nama anak dari perkawinan tidak tercatat dapat dimuat dalam surat keterangan tersebut, sehingga surat keterangan waris yang memuat nama anak dari perkawinan tidak tercatat, tidak mempunyai kekuatan hukum, dan oleh sebab itu disarankan agar pemerintah segera membuat peraturan tentang pembuatan surat keterangan waris bagi anak dari perkawinan tidak tercatat, sehingga memiliki kekuatan hukum yang jelas dan tetap, serta mengikat secara umum.

Kata Kunci: Ahli Waris; Anak Luar Kawin; Surat Keterangan Ahli Waris

\section{A. PENDAHULUAN}

Perkawinan dilangsungkan harus berdasarkan pada norma hukum yang berlaku dalam masyarakat, yaitu norma hukum dalam ajaran agama pada satu sisi, dan norma hukum yang terdapat dalam peraturan perundang-undangan pada sisi lainnya. Hal ini sesuai dengan Pasal 2 ayat (1) dan ayat (2) Undang-undang Nomor 1 Tahun 1974 tentang Perkawinan (UU No. 1 Tahun 1974), yang menentukan bahwa perkawinan adalah sah apabila dilakukan menurut hukum masing-masing agamanya dan kepercayaannya itu, dan tiap-tiap perkawinan dicatat menurut peraturan perundang-undangan yang berlaku. Berdasarkan ketentuan ini, dapat diasumsikan bahwa untuk sahnya perkawinan, maka selain harus sah berdasarkan agama, juga harus dicatat, sehingga perkawinan mempunyai kekuatan hukum dan dapat dibuktikan atau peristiwa perkawinan itu telah diakui oleh negara. Hal ini penting artinya demi kepentingan suami isteri itu sendiri, anak yang lahir dari perkawinan, serta harta yang ada dalam perkawinan.

Tujuan pencatatan perkawinan dilakukan agar perkawinan yang telah dilangsungkan mempunyai kekuatan hukum yang kuat dan pasti. Kepastian hukum inilah yang mengakibatkan timbulnya hak-hak dan kewajiban antara suami-isteri, anak yang dilahirkan menjadi anak yang sah, hak dan kewajiban orang tua terhadap anaknya, hak saling mewarisi antara suami-isteri dan anak-anak dengan orang tua, dan bagi anak perempuan bapaknya berhak menjadi wali nikahnya (Ramulyo, 1996: 248). Abdurrahman dan Syahrani (1986: 16) menyatakan bahwa:

"Jika suatu perkawinan tidak dicatat, maka walaupun perkawinan tersebut sah menurut ajaran agama atau kepercayaan, perkawinan tersebut tidak diakui oleh negara, begitu pula akibat yang timbul dari perkawinan itu, sedangkan salah satu tujuan dari perkawinan adalah untuk mendapatkan anak dan akibat dari perkawinan adalah tanggung jawab orang tua terhadap anak-anak yang dilahirkan dari perkawinan."

Selain perkawinan yang dicatatkan, dalam kehidupan masyarakat ada praktik perkawinan yang tidak dicatatkan, yang dikenal dengan istilah perkawinan siri (Sarwanto, 2013: 193). Pengertian perkawinan siri yang berkembang dalam masyarakat saat ini adalah suatu perkawinan yang dilakukan oleh kedua mempelai dengan memenuhi rukun dan syarat-syarat perkawinan menurut ketentuan hukum 
agama, tetapi proses perkawinan tersebut tidak dilakukan di hadapan pegawai pencatat perkawinan, dan tentunya perkawinan tersebut tidak tercatat dalam daftar catatan perkawinan di Kantor Pencatatan Perkawinan, serta tidak memiliki surat nikah yang dikeluarkan oleh pemerintah (Witanto, 2012: 151; Muhammadi, 2017: 2 \& 4).

Perkawinan siri pada prinsipnya perkawinan yang dilakukan di luar ketentuan hukum perkawinan yang berlaku di Indonesia. Walaupun keabsahannya menurut Hukum Islam tidak terganggu, karena dalam hal ini hanya menyangkut masalah administratif saja, tetapi akibatnya, tidak dicatatkannya perkawinan berimplikasi pada tidak adanya bukti otentik bahwa suami dan isteri telah melangsungkan perkawinan, sehingga tidak mempunyai kekuatan hukum (no legal force), dan perkawinan tersebut tidak dilindungi oleh hukum, bahkan dianggap tidak pernah ada (Anshary, 2010: 30).

Hukum hanya melindungi perkawinan yang dilakukan berdasarkan ketentuan Pasal 2 ayat (1) dan ayat (2) UU No. 1 Tahun 1974. Istilah "tidak mempunyai kekuatan hukum" sebagaimana kutipan dalam Pasal 6 ayat (2) KHI, dan menurut Anshary (2014: 133), dijelaskan bahwa perkawinan tersebut dinyatakan tidak pernah ada (never existed), dan lebih jauh lagi perkawinan semacam itu tidak dilindungi oleh hukum (no legal protection). Hak-hak dari berbagai pihak dalam perkawinan akan dijamin pelaksanannya melalui pencatatan perkawinan, sehingga tidak ada pihak yang dirugikan. Seorang isteri yang ingin menuntut nafkah lahir harus dilaksanakan oleh seorang suami atas dasar tuntutan dari undang-undang, hak waris anak terhadap harta pewaris tidak akan hilang, walaupun pewaris tidak menginginkan harta tersebut jatuh ke tangan anaknya, dan hal ini merupakan perlindungan hukum terhadap para pihak dari perkawinan sah.

Pencatatan perkawinan menjadi penting fungsinya dalam perspektif hukum positif di Indonesia, yang pada akhirnya bertujuan untuk membedakan antara keturunan sah dan keturunan tidak sah. Keturunan sah didasarkan atas adanya pekawinan yang sah, dalam arti bahwa yang satu adalah keturunan yang lain berdasarkan kelahiran dalam atau sebagai akibat perkawinan yang sah, anak-anak yang demikian disebut anak sah, sedangkan keturunan tidak sah adalah keturunan yang tidak didasarkan atas suatu perkawinan yang sah, atau dalam istilah lain disebut dengan anak luar kawin.

Ada berbagai alasan terjadinya anak luar kawin, yang menurut Witanto (2012: 146-147), dikatakan bahwa berdasarkan sebab atau latar belakangnya, anak luar kawin terjadi karena:

1. Anak yang dilahirkan oleh seorang wanita, tetapi wanita itu tidak mempunyai ikatan perkawinan dengan pria yang menyetubuhinya dan tidak mempunyai ikatan perkawinan dengan pria atau wanita lain; 
2. Anak yang lahir dari seorang wanita, kelahiran tersebut diketahui dan dikehendaki oleh salah satu atau ibu bapaknya, hanya saja salah satu atau kedua orang tuanya itu masih terkait dengan perkawinan yang lain;

3. Anak yang lahir dari seorang wanita, tetapi pria yang menghamilinya itu tidak diketahui, misalnya akibat korban perkosaan;

4. Anak yang lahir dari seorang wanita dalam masa iddah perceraian, tetapi anak yang dilahirkan itu merupakan hasil hubungan dengan pria yang bukan suaminya. Ada kemungkinan anak di luar kawin ini dapat diterima oleh keluarga kedua belah pihak secara wajar, jika wanita yang melahirkan itu kawin dengan pria yang menyetubuhinya;

5. Anak yang lahir dari seorang wanita yang ditinggal suami lebih dari 300 hari, anak tersebut tidak diakui oleh suaminya sebagai anak yang sah;

6. Anak yang lahir dari seorang wanita, padahal agama yang mereka peluk menentukan lain, misalnya dalam agama Katholik tidak mengenal adanya cerai hidup, tetapi dilakukan juga, kemudian ia kawin lagi dan melahirkan anak. Anak tersebut dianggap anak di luar kawin;

7. Anak yang lahir dari seorang wanita, sedangkan pada mereka berlaku ketentuan negara melarang mengadakan perkawinan misalnya Warga Negara Indonesia (WNI) dan Warga Negara Asing (WNA) tidak mendapat ijin dari Kedutaan Besar untuk mengadakan perkawinan, karena salah satunya dari mereka telah mempunyai isteri, tetapi mereka tetap campur dan melahirkan anak tersebut anak ini dinamakan juga anak luar kawin;

8. Anak yang dilahirkan dari seorang wanita, tetapi anak tersebut sama sekali tidak mengetahui kedua orang tuanya;

9. Anak yang lahir dari perkawinan yang tidak dicatat di Kantor Catatan Sipil dan/atau Kantor Urusan Agama; atau

10. Anak yang lahir dari perkawinan secara adat tidak dilaksanakan menurut agama dan kepercayaan, serta tidak didaftar di Kantor Catatan Sipil dan Kantor Urusan Agama.

Terkait dengan berbagai sebab atau latar belakang terjadinya anak luar kawin sebagaimana tersebut di atas, maka dalam penelitian ini dibatasi bahwa yang dimaksud dengan anak luar kawin hanyalah anak yang perkawinan orang tuanya sah menurut hukum agama, tetapi tidak dicatat dalam buku/akta nikah oleh pejabat yang berwenang. Pembatasan ini dimaksudkan untuk mengkaji lebih jauh terhadap hak waris anak luar kawin dimaksud, mengingat adanya Putusan Mahkamah Kontitusi Nomor: 46/PUU-VIII/2010, yang diputuskan tanggal 13 Pebruari 2012, dalam permohonan uji materil terhadap Pasal 43 ayat (1) UU No. 1 Tahun 1974 yang diajukan oleh Aisyah Mochtar alias Machica binti Mochtar Ibrahim dengan Muhammad Iqbal Ramadhan bin Moerdiono, yang isinya memutuskan antara lain:

1. Pasal 43 ayat (1) Undang-undang Nomor 1 Tahun 1974 tentang Perkawinan (Lembaran Negara Republik Indonesia Tahun 1974 Nomor 1, Tambahan Lembaran Negara Republik Indonesia Nomor 3019) yang menyatakan, “Anak 
yang dilahirkan di luar perkawinan hanya mempunyai hubungan perdata dengan ibunya dan keluarga ibunya", bertentangan dengan Undang-Undang Dasar Negara Republik Indonesia Tahun 1945 sepanjang dimaknai menghilangkan hubungan perdata dengan laki-laki yang dapat dibuktikan berdasarkan ilmu pengetahuan dan teknologi dan/atau alat bukti lain menurut hukum ternyata mempunyai hubungan darah sebagai bapaknya; dan

2. Pasal 43 ayat (1) Undang-undang Nomor 1 Tahun 1974 tentang Perkawinan (Lembaran Negara Republik Indonesia Tahun 1974 Nomor 1, Tambahan Lembaran Negara Republik Indonesia Nomor 3019) yang menyatakan, "Anak yang dilahirkan di luar perkawinan hanya mempunyai hubungan perdata dengan ibunya dan keluarga ibunya", tidak memiliki kekuatan hukum mengikat sepanjang dimaknai menghilangkan hubungan perdata dengan lakilaki yang dapat dibuktikan berdasarkan ilmu pengetahuan dan teknologi dan/atau alat bukti lain menurut hukum ternyata mempunyai hubungan darah sebagai bapaknya, sehingga ayat tersebut harus dibaca, "Anak yang dilahirkan di luar perkawinan mempunyai hubungan perdata dengan ibunya dan keluarga ibunya, serta dengan laki-laki sebagai bapaknya yang dapat dibuktikan berdasarkan ilmu pengetahuan dan teknologi dan/atau alat bukti lain menurut hukum mempunyai hubungan darah, termasuk hubungan perdata dengan keluarga bapaknya."

Putusan Mahkamah Konstitusi ini telah menimbulkan kontroversi, sebagian pendapat menyatakan bahwa putusan ini akan memberikan perubahan hukum ke arah yang lebih baik dalam upaya perlindungan hak-hak anak di mata hukum dan masyarakat umumnya, sedangkan pendapat lain di kalangan masyarakat berkembang pemahaman bahwa putusan ini akan banyak menimbulkan kerumitan dan persoalan baru yang bersinggungan dengan hukum waris yang berlaku di Indonesia dan mengubah tatanan kehidupan umat Islam (waris Islam) yang selama ini berlaku, bahkan sebagian besar masyarakat menyatakan bahwa putusan ini telah melegalisasi perzinahan di Indonesia (Ibrahim, Nurbaeti, dan Yunardi, 2012: 47). Mahfud MD sebagaimana dikutip Hairi (2012: 3) tidak membantah pandangan tersebut, sekaligus ia berpendapat bahwa Putusan Mahkamah Konstitusi justru bermaksud menghindari semakin meluasnya perzinahan, dan semangat yang digunakan hakim Mahkamah Konstitusi dalam memutus perkara adalah semangat menghindari perzinahan. Khisni (2014: 316), juga mengatakan bahwa Putusan Mahkamah Konstitusi Nomor: 46/PUU-VIII/2010 hanya menyangkut anak hasil dari perkawinan siri (perkawinan tidak tercatat) bukan anak zina.

Perkawinan dan pencatatan perkawinan merupakan 2 (dua) peristiwa yang berbeda, sehingga masalah keabsahan perkawinan tidak tergantung kepada persoalan pencatatan perkawinan. Sahnya perkawinan apabila perkawinan tersebut dilaksanakan menurut agama atau kepercayaan, dengan demikian jika menurut agama suatu perkawinan adalah sah, maka perkawinan tersebut sah secara yuridis (Rahmi dan Sakdul, 2016: 277). Menurut Tengku Erwinsyahbana (2012: 330) 
dikatakan pula bahwa pencatatan perkawinan merupakan kewajiban untuk dilaksanakan, tidak menjadi ukuran sah atau tidak sahnya perkawinan, karena berdasarkan Pasal 2 Perpres No. 25 Tahun 2008, pencatatan sipil hanya bertujuan untuk memberikan "keabsahan identitas" dan "kepastian hukum atas dokumen penduduk", "perlindungan status hak sipil penduduk", dan "mendapatkan data yang mutahir, benar dan lengkap", jadi tidak untuk menjadi ukuran atau alasan sahnya perkawinan.

Dapat diperhatikan pendapat Muhamad Arifin (2017: 124) yang mengatakan bahwa anak yang lahir di luar perkawinan adalah anak yang lahir dari perkawinan yang dilakukan menurut masing-masing agamanya dan kepercayaannya, tetapi tidak tercatat oleh Pegawai Pencatat Nikah, dan perkawinan yang demikian "sah" dalam perspektif fikih Islam sepanjang memenuhi syarat dan rukun perkawinan. Istilah luar perkawinan maksudnya adalah dilakukan di luar prosedur Pasal 2 ayat (2) UU No. 1 Tahun 1974 tidak dapat diartikan sebagai perzinaan, karena perbuatan zina itu dilakukan sama sekali tanpa ada perkawinan. Terdapat perbedaan istilah antara "luar perkawinan" dengan "tanpa perkawinan". Analoginya bandingkan dengan kata-kata: "tidur di luar rumah", artinya "rumahnya ada, tetapi tidur di luarnya", tetapi jika "tidur tanpa rumah", berarti "rumahnya tidak ada". Oleh karena itu jika disebut "perkawinan", berarti perkawinan itu sudah dilakukan minimal sesuai dengan Pasal 2 ayat (1) UU No. 1 Tahun 1974, dan hal ini yang disebut "luar perkawinan", sedangkan perzinaan sama sekali tidak tersentuh dengan terminologi "perkawinan".

Berdasarkan pendapat yang diuraikan di atas dan memperhatikan Putusan Mahkamah Konstitusi Nomor: 46/PUU-VIII/2010, dapat diasumsikan bahwa terhadap anak luar kawin akibat perkawinan orang tuanya yang tidak dicatat, tetap masih mempunyai hubungan perdata dengan bapaknya, sehingga menimbulkan konsekuensi hukum bahwa anak tersebut tetap mempunyai hak untuk mewarisi harta yang ditinggalkan bapaknya, dan untuk memperoleh kepastian hukum terhadap haknya sebagai ahli waris, maka dalam surat keterangan ahli waris seharusnya nama anak luar kawin dimaksud dapat disebutkan sebagai ahli waris selain para ahli waris lainnya yang sah secara yuridis, tetapi hal ini belum diatur dalam peraturan perundang-undangan di Indonesia. Fakta yang demikian ini tentunya menarik untuk diteliti, guna memperoleh jawaban yang terkait dengan kekuatan hukum surat keterangan ahli waris yang memuat nama anak luar kawin dari perkawinan yang tidak tercatat. 


\section{B. METODOLOGI PENELITIAN}

Penelitian ini merupakan penelitian hukum normatif, karena data yang digunakan adalah data sekunder yang relevan dengan permasalahan yang akan dianalisis, baik berupa bahan hukum primer, bahan hukum sekunder maupun bahan hukum tersier. Hal ini didasarkan pada pendapat Soerjono Soekanto dan Sri Mamudji (2003: 14) yang mengatakan bahwa penelitian hukum normatif adalah penelitian yang objek kajiannya terkait dengan data sekunder. Pendekatan penelitian ini adalah pendekatan perundang-undangan, berhubung yang akan diteliti adalah aturan hukum yang menjadi fokus sekaligus tema sentral suatu penelitian, karena menurut Johnny Ibrahim (2006: 300), dikatakan bahwa salah satu pendekatan penelitian hukum normatif atau penelitian kepustakaan adalah pendekatan perundang-undangan (statute approach).

Sifat penelitian ini adalah deskriptif, yaitu penelitian yang bertujuan untuk membuat gambaran secara sistematik, faktual, dan akurat mengenai fakta-fakta, sifat-sifat serta hubungan fenomena yang diselidiki (Soekanto, 1998: 3), khususnya terkait fakta-fakta yuridis mengenai kekuatan hukum akta waris yang dibuat untuk anak yang lahir dari perkawinan yang tidak tercatat, sedangkan sumber data penelitian adalah data sekunder, yang terdiri dari:

1. bahan hukum primer, yaitu berupa peraturan perundang-undangan yang ada hubungannya dengan pokok permasalahan yang diteliti, antara lain:

a. Undang Undang Dasar Negara Republik Indonesia Tahun 1945

b. Undang-undang Nomor 1 Tahun 1974 tentang Perkawinan

c. Undang-undang Nomor 3 Tahun 2006 tentang Perubahan atas Undangundang Nomor 7 Tahun 1989 tentang Peradilan Agama

d. Undang-undang Nomor 23 Tahun 2006 tentang Administrasi Kependudukan

e. Undang-undang Nomor 2 Tahun 2014 tentang Perubahan Atas Undangundang Nomor 30 Tahun 2004 tentang Jabatan Notaris

f. Peraturan Pemerintah Nomor 24 Tahun 1997 tentang Pendaftaran Tanah

g. Peraturan Pemerintah Nomor 37 Tahun 2007 tentang pelaksanaan Undang-undang Nomor 23 Tahun 2006 tentang Administrasi kependudukan

h. Peraturan Presiden Nomor 25 Tahun 2008 tentang Persyaratan dan Tata Cara Pendaftaran Penduduk dan Pencatatan Sipil

i. Instruksi Presiden Nomor 1 Tahun 1991 tentang Kompilasi Hukum Islam

j. Peraturan Menteri Negara Agraria/Kepala Badan Pertanahan Nasional Nomor 3 Tahun 1997 tentang Pelaksanaan Peraturan Pemerintah Nomor 24 Tahun 1997 tentang Pendaftaran Tanah

k. Surat Edaran Departemen Dalam Negeri Direktorat Jenderal Agraria Tanggal 20 Desember 1969 Nomor Dpt/12/63/12/69 tentang Surat Keterangan Warisan dan Pembuktian Kewarganegaraan.

l. Putusan Mahkamah Konstitusi Indonesia Nomor 46/PUU-VII/2010. 
2. bahan hukum sekunder, yaitu bahan yang memberikan penjelasan mengenai bahan hukum primer, yaitu berupa hasil penelitian dan karya ilmiah serta buku-buku hukum dan jurnal ilmiah yang ada hubungannya dengan pokok permasalahan yang diteliti; dan

3. bahan hukum tertier, yakni bahan-bahan yang memberikan petunjuk maupun penjelasan terhadap bahan hukum primer dan bahan hukum sekunder, seperti kamus, majalah dan internet.

Pengumpulan data dalam penelitian ini mempergunakan data sekunder yang diperoleh melalui studi kepustakaan (literature research). Studi kepustakaan merupakan suatu metode pengumpulan data yang dilakukan dengan membaca bahan-bahan hukum yang ada relevansinya dengan topik pembahasan atau masalah yang akan diteliti, baik bahan hukum primer, bahan hukum sekunder, maupun bahan hukum tersier. Setelah pengumpulan data dilaksanakan, maka data tersebut dipilah-pilah sesuai pokok permasalahan yang diteliti, dan kemudian dianalisis secara kualitatif, yakni dengan mengadakan pengamatan data yang diperoleh dan menghubungkan tiap-tiap data tersebut dengan ketentuan-ketentuan maupun asasasas hukum yang terkait dengan permasalahan yang diteliti, sehingga dapat ditarik kesimpulan dari penelitian mengenai kekuatan hukum surat keterangan ahli waris yang dibuat untuk anak yang lahir dari perkawinan tidak tercatat.

\section{PEMBAHASAN}

\section{Perlindungan dan Kepastian Hukum Anak di Luar Kawin}

Hukum hendaknya harus dapat difungsikan untuk melindungi manusia dan masyarakat Indonesia, yang tidak terlepas dari tujuan politik hukum yang memuat cita-cita Negara Republik Indonesia, sebagaimana yang dinyatakan dalam alinea keempat Pembukaan Undang Undang Dasar (UUD) 1945, yaitu:

a. untuk melindungi segenap bangsa dan seluruh tumpah darah Indonesia;

b. untuk memajukan kesejahteraan umum;

c. mencerdaskan kehidupan bangsa; dan

d. ikut memelihara ketertiban dunia.

Terkait dengan perlindungan hukum ini, Satjipto Rahardjo (1983: 121) mengemukakan bahwa:

"Perlindungan hukum adalah upaya melindungi kepentingan seseorang dengan cara mengalokasikan suatu kekuasaan kepadanya untuk bertindak dalam kepentingannya tersebut. Salah satu sifat dan sekaligus merupakan tujuan dari hukum adalah memberikan perlindungan (pengayoman) kepada masyarakat. Oleh karena itu, perlindungan hukum terhadap masyarakat tersebut harus diwujudkan dalam bentuk adanya kepastian hukum."

Perlindungan hukum merupakan suatu hal yang melindungi subyek-subyek hukum melalui peraturan perundang-undangan yang berlaku dan dipaksakan pelaksanaannya dengan suatu sanksi (Setiono, 2004: 3). Menurut Philipus M. Hadjon (1987: 38) dikatakan bahwa: 
"Dalam merumuskan prinsip-prinsip perlindungan hukum di Indonesia, landasannya adalah Pancasila sebagai ideologi dan falsafah negara. Konsepsi perlindungan hukum bagi rakyat di Barat bersumber pada konsep-konsep "rechtstaat" dan "rule of the law". Dengan menggunakan konsepsi Barat sebagai kerangka berfikir dengan landasan pada Pancasila, prinsip perlindungan hukum di Indonesia adalah prinsip pengakuan dan perlindungan terhadap harkat dan martabat manusia yang bersumber pada Pancasila. Prinsip perlindungan hukum terhadap tindak pemerintah bertumpu dan bersumber dari konsep tentang pengakuan dan perlindungan terhadap hak-hak asasi manusia karena menurut sejarahnya di Barat, lahirnya konsep-konsep tentang pengakuan dan perlindungan terhadap hakhak asasi menusia diarahkan kepada pembatasan-pembatasan dan peletakan kewajiban masyarakat dan pemerintah."

Sesuai dengan pendapat di atas, maka menurut Tengku Erwinsyahbana

(2012: 22) dikatakan bahwa:

"Pencapaian tujuan hukum memerlukan suatu perangkat aturan hukum yang jelas dan memadai yang sesuai dengan aturan norma-norma yang terdapat dalam masyarakat negara bersangkutan. Selain itu tentunya juga memerlukan alat perlengkapan negara untuk memaksakan atau menjalankan kekuasaannya, sehingga hukum itu efektif, tetapi dalam negara hukum, kekuasaan tersebut tetap di batasi oleh hukum dan hukum yang dimaksud adalah hukum yang sesuai dengan nilai-nilai yang terkandung dalam Pancasila."

Pencapaian tujuan hukum sebagaimana diuraikan di atas, tentunya harus diwujudkan melalui peraturan perundang-undangan, yang sekaligus bertujuan untuk menciptakan kepastian hukum, karena menurut Jan Michiel Otto (2003: 5), dikatakan bahwa:

"Untuk menciptakan kepastian hukum, harus memenuhi syarat-syarat, sebagai berikut:

a. Ada aturan hukum yang jelas dan konsisten;

b. Instansi pemerintah menerapkan aturan hukum secara konsisten, tunduk dan taat terhadapnya;

c. Masyarakat menyesuaikan perilaku mereka terhadap aturan hukum tersebut;

d. Hakim-hakim yang mandiri, tidak berpihak dan harus menerapkan aturan hukum secara konsisten serta jeli sewaktu menyelesaikan sengketa hukum;

e. Putusan pengadilan secara konkrit dilaksanakan."

Banyak aspek yang terkait dengan kehidupan masyarakat telah diwujudkan dalam bentuk undang-undang demi menjamin terciptanya kepastian hukum, tetapi faktanya walaupun diwujudkan dalam bentuk undang-undang, ternyata dalam pengimplementasiannya tidak dipatuhi oleh masyarakat. Salah satu faktor tidak dipatuhinya undang-undang, karena dianggap bertentangan dengan perasaan keadilan ataupun cita hukum masyakat, dan oleh sebab itu guna mewujudkan kepastian hukum tidak dapat dilakukan hanya dengan membentuk undang-undang. 
Hal terpenting yang juga perlu diperhatikan adalah terkait dengan cita hukum masyarakat, karena apabila cita hukum ini diabaikan dalam pembentukan peraturan perundang-undangan, justru dapat menyebabkan ketidakpastian hukum.

Pandangan tersebut di atas sesuai pendapat Gustav Radbruch (dalam Riyanto (2002: 377) yang mengatakan bahwa:

"Gagasan hukum merupakan gagasan kultural tidak bisa formal, berarti terarah pada cita hukum (rechtsidee), yaitu keadilan. Untuk mengisi cita keadilan ini dengan isi yang konkrit harus dilihat dari sisi finalitasnya, dan untuk melengkapi cita hukum serta finalitas, dibutuhkan kepastian. Oleh sebab itu, hukum memiliki 3 (tiga) aspek penting, yaitu: keadilan, kepastian dan finalitas. Aspek keadilan menunjukkan pada kesamaan hak di depan hukum, aspek finalitas menunjukkan pada tujuan keadilan yaitu memajukan kebaikan dalam hidup manusia, berarti menentukan isi hukum, sedangkan aspek kepastian menunjukkan pada jaminan bahwa hukum (yang berisi keadilan dan norma-norma yang memajukan kebaikan), dan benar-benar berfungsi sebagai peraturan yang harus ditaati. Aspek keadilan merupakan kerangka ideal dari hukum, sedangkan aspek kepastian merupakan kerangka operasional hukum".

Terhadap istilah kepastian hukum, ada beberapa pengertian yang dapat dikemukakan. Berdasarkan terjemahan resmi dari Badan Pembinaan Hukum Nasional (1997/1998: 122), disebutkan bahwa kepastian hukum (rechtszekerheid) merupakan jaminan bagi anggota masyarakat bahwa hukum akan diterapkan secara benar dan adil, sedangkan dalam Kamus Besar Bahasa Indonesia (2002: 835), disebutkan bahwa kepastian hukum adalah perangkat hukum suatu negara yang mampu menjamin hak dan kewajiban setiap warga negara.

Menurut Jimly Ashiddiqie (http://www.suarakarya-online.com, diakses tanggal 12 Maret 2017), dikatakan bahwa:

"Dalam hukum harus ada keadilan dan kepastian hukum dan kepastian hukum itu penting agar orang tidak bingung, tetapi keadilan dan kepastian hukum itu sendiri merupakan dua sisi dari satu mata uang. Antara keadilan dan kepastian hukum tidak perlu dipertentangkan. Kalimatnya tidak boleh dipotong, berarti keadilan pasti identik dengan kepastian yang adil. Kalau ketidakpastian itu terjadi, berarti terjadi ketidakadilan bagi banyak orang. Jangan karena ingin mewujudkan keadilan bagi satu orang, tetapi justru menciptakan ketidakadilan bagi banyak orang. Selain harus ada kepastian hukum, tujuan hukum adalah untuk mewujudkan keadilan dan keteraturan. Keadilan, kepastian hukum, dan keteraturan itu harus diwujudkan secara simultan agar tercipta kedamaian hidup bersama."

Kepastian hukum, sebagaimana disampaikan Apeldoorn (dalam Darmodiharjo dan Shidarta, 1996: 44) mempunyai dua segi, yaitu: 1) soal dapat ditentukannya (bepaalbaarheid) hukum dalam hal-hal yang konkrit, artinya pihak-pihak yang 
mencari keadilan ingin mengetahui apa yang menjadi hukumnya dalam hal yang khusus, sebelum ia memulai suatu perkara, dan b) kepastian hukum berarti keamanan hukum, artinya perlindungan bagi para pihak terhadap kesewenangan hakim (Apeldoorn dalam Darji Darmodiharjo dan Shidarta, 1996: 44). Menurut Reinhold Zippelius (dalam Suseno, 2001: 79-80), kepastian hukum dibedakan dalam dua pengertian, yaitu:

a. Kepastian dalam pelaksanaannya, maksudnya bahwa hukum yang resmi diundangkan dilaksanakan dengan pasti oleh negara. Setiap orang dapat menuntut agar hukum dilaksanakan dan tuntutan itu pasti dipenuhi dan setiap pelanggaran hukum akan ditindak dan dikenakan sanksi menurut hukum juga; dan

b. Kepastian orientasi, maksudnya bahwa hukum itu harus jelas, sehingga masyarakat dan hakim dapat berpedoman padanya. Hal ini berarti bahwa setiap istilah dalam hukum harus dirumuskan dengan terang dan tegas sehingga tak ada keragu-raguan tentang tindakan apa yang dimaksud. Begitu pula aturan-aturan hukum harus dirumuskan dengan ketat dan sempit agar keputusan dalam perkara pengadilan tidak dapat menurut tafsiran subyektif dan selera pribadi hakim. Kepastian orientasi menuntut agar ada prosedur pembuatan dan peresmian hukum yang jelas dan dapat diketahui umum. Kepastian orientasi ini juga menuntut agar hukum dikembangkan secara kontinu dan taat asas. Undang-undang harus saling kait mengkait, harus menunjuk ke satu arah agar masyarakat dapat membuat rencana ke masa depan, begitu pula jangan dibuat undangundang yang saling bertentangan.

Beranjak dari teori-teori yang diuraikan di atas, dengan melihat fakta bahwa anak yang dilahirkan tanpa memiliki kejelasan status bapak, seringkali mendapatkan perlakuan yang tidak adil di tengah masyarakat, padahal hukum harus memberi perlindungan dan kepastian hukum yang adil terhadap status seorang anak yang dilahirkan dan hak-hak yang ada padanya (termasuk pula anak yang lahir dari perkawinan tidak tercatat). Hal ini terjadi karena adanya substansi ketentuan Pasal 43 UU No. 1 Tahun 1974, yang menentukan bahwa anak yang lahir dari perkawinan tidak tercatat dimaknai juga sebagai anak luar kawin, sehingga tidak mempunyai hubungan perdata dengan bapak biologisnya.

Dalam perspektif substansi hukum (kepastian orientasi), dapat dikatakan bahwa Pasal 43 UU No. 1 Tahun 1974 telah mengabaikan kepastian hak-hak anak yang lahir dari perkawinan tidak tercatat, walaupun secara agama perkawinan tersebut adalah sah. Terkait Pasal 43 ayat (1) UU No. 1 Tahun 1974, maka untuk mewujudkan perlindungan dan kepastian hukum bagi hak-hak anak, maka harus dimaknai bahwa anak yang dilahirkan di luar perkawinan, mempunyai hubungan perdata dengan ibunya dan keluarga ibunya, serta dengan laki-laki sebagai bapaknya yang dapat dibuktikan berdasarkan ilmu pengetahuan dan teknologi dan/atau alat bukti lain menurut hukum mempunyai hubungan darah, termasuk 
hubungan perdata dengan keluarga bapaknya. Selain itu, apabila dikaitkan dengan permasalahan anak yang masih dalam kandungan ibunya (khususnya hak waris anak dalam pernikahan siri), dan mengingat banyaknya praktik masyarakat yang melakukan pernikahan siri, maka dibutuhkan kepastian hukum dalam menyelesaikan setiap permasalahan kewarisan dengan berpedoman pada kebijakan atau aturan-aturan yang ditetapkan pemerintah maupun aturan-aturan yang ada dalam masyarakat dengan melindungi hak-hak anak yang dilahirkan maupun yang masih dalam kandungan.

Sesuai dengan Putusan Mahkamah Konstitusi Nomor 46/PUU-VIII/2010, maka telah diakui hak anak luar kawin untuk dapat membuktikan keberadaan dirinya dengan ilmu pengetahuan mempunyai hubungan dengan bapaknya, dan jika terbukti maka dia memiliki hak waris yang sama dengan ahli waris lainnya, dan terhadap anak yang masih dalam kandungan yang berasal dari pernikahan siri juga harus mendapatkan kepastian hukum terhadap hak-haknya. Putusan ini sekaligus merupakan upaya pemberian perlindungan hukum terhadap hak-hak anak yang lahir dari perkawinan tidak tercatat, yang perkawinan tersebut sah menurut hukum agama.

\section{Kewenangan dalam Pembuatan Surat Keterangan Ahli Waris}

Terkait dengan proses pembuatan surat keterangan ahli waris, ada beberapa aturan yang berlaku dan menentukan bahwa untuk pembuatan surat keterangan ahli waris bagi masing-masing golongan penduduk dilaksanakan pada institusi berbeda. Beberapa ketentuan (peraturan atau regulasi lain) yang terkait dengan pembuatan surat keterangan ahli waris ini terdapat dalam:

a. Undang-undang Nomor 30 Tahun 2004 tentang Jabatan Notaris (UU No. 30 Tahun 2004) sebagaimana telah diubah dengan Undang-undang Nomor 2 Tahun 2014 tentang Perubahan Atas Undang-undang Nomor 30 Tahun 2004 tentang Jabatan Notaris (UU No. 2 Tahun 2014). Sebenarnya tidak ada ketentuan secara tegas dan khusus yang mengatur kewenangan notaris dalam membuat surat keterangan ahli waris, tetapi kewenangan ini hanya didasarkan pada kebiasaan yang diikuti dari notaris pada masa penjajahan Belanda. Notaris membuat surat keterangan ahli waris hanya didasarkan pada suatu kebiasaan dari notaris-notaris zaman kolonial Belanda, dan apabila dikronologikan peraturan-peraturan terkait wewenang notaris dalam membuat surat keterangan waris dari dahulu sampai saat ini, maka dapat diketahui ketentuan sebagai berikut:

1) Wet $O p$ Het Notarisambt, yaitu Undang-undang Jabatan Notaris yang berlaku di Belanda yang diundangkan pada bulan Juli 1842, dan mengenai surat keterangan waris diatur dalam Pasal 38 ayat (2), menentukan bahwa seorang notaris yang biasanya diharuskan membuat akta-akta dengan minuta, dibebaskan dari kewajiban tersebut apabila membuat akta-akta tertentu. Termasuk dalam 
akta-akta yang disebut terakhir ini adalah verklaring van erfrecht (Kie, 2011: 565).

2) Reglement op het Notarisambt, dari wet op het notarisambt di negeri Belanda, diberlakukan berdasarkan asas konkordansi dalam Reglement op het Notarisambt (Peraturan Jabatan Notaris) tanggal 11 januari 1860 (Stb. 1860 No. 3), yaitu dalam Pasal 35, tetapi ketentuan ini tidak sama persis dengan wet op het Notarisambt (Tobing. 1999: 228).

3) Grootbroeken der Nationale schuld, yang dikeluarkan pada tahun 1913 di Belanda. Dalam Pasal 14 diatur tentang surat keterangan waris bagi ahli waris yang pewarisnya memiliki suatu hak terdaftar dalam buku besar utang-utang nasional. Dalam ayat (1) ditentukan bahwa para ahli waris tersebut harus membuktikan hak mereka dengan suatu keterangan waris setelah ada pembuktian tentang kematian pewaris; ayat (2) mengatur hal-hal yang harus dimuat dalam keterangan waris; ayat (3) mengatur bahwa notaris yang membuat akta keterangan tersebut dalam bentuk in originali (warisan terbuka di negeri Belanda); ayat (4) mengatur bahwa bila pejabat yang berwenang di wilayah tersebut; ayat (5) menentukan dokumen pembuktian fakta-fakta yang tertulis turut dilampirkan dalam akta tersebut; dan terakhir pada ayat (6) ditentukan bahwa penerima hibah wasiat juga harus membuktikan haknya seperti ahli waris (Kie, 2011: 566). Hal yang perlu diperhatikan bahwa wet op de Grootboeken der Nationale schuld adalah undang-undang yang berlaku di Belanda pada waktu itu, tetapi pengaturan mengenai keterangan waris yang jelas terdapat pada undang-undang ini, tidak pernah diberlakukan di Hindia Belanda (Indonesia) pada masa lampau, dan tidak pernah undang-undang ini dibuat dalam bentuk reglement atau peraturan yang berlaku pada daerah jajahan.

b. Undang-undang Nomor 7 Tahun 1989 tentang Peradilan Agama sebagaimana telah diubah dengan Undang-undang Nomor 3 Tahun 2006 tentang Perubahan atas Undang-undang Nomor 7 Tahun 1989 tentang Peradilan Agama, yang berdasarkan Pasal 49 huruf b ditentukan bahwa bagi penduduk Indonesia yang beragama Islam, dalam mengeluarkan surat keterangan ahli waris, pihak yang berwenang mengeluarkan penetapan mengenai pembagian harta peninggalan seorang pewaris yang beragama Islam adalah Pengadilan Agama.

c. Pasal 42 ayat (1) Peraturan Pemerintah Nomor 24 Tahun 1997 tentang Pendaftaran Tanah jo Pasal 111 Ayat (1) Huruf c Angka 4 Peraturan Menteri Negara Agraria/Kepala Badan Pertanahan Nasional Nomor 3 Tahun 1997 tentang Pelaksanaan Peraturan Pemerintah Nomor 24 Tahun 1997 tentang Pendaftaran Tanah, yang mengatur tentang peralihan hak karena pewarisan dan dokumen-dokumen yang diperlukan untuk kepentingan pendaftaran 
peralihan hak karena pewarisan yang salah satunya adalah surat keterangan ahli waris. Peraturan Menteri Negara Agraria/Kepala Badan Pertanahan Nasional Nomor 3 Tahun 1997, mengatur lebih lanjut ketentuan penggunaan surat keterangan waris sebagai salah satu dokumen yang digunakan dalam proses pendaftaran tanah yang terjadi karena pewarisan, bahwa:

1) Bagi Warga Negara Indonesia penduduk asli: surat keterangan ahli waris yang dibuat oleh para ahli waris dengan disaksikan oleh 2 (dua) orang saksi dan dikuatkan oleh Kepala Desa/Kelurahan dan Camat tempat tinggal pewaris pada waktu meninggal.

2) Bagi Warga Negara Indonesia keturunan Tionghoa: akta keterangan hak mewaris dari notaris.

3) Bagi Warga Negara Indonesia keturunan Timur Asing lainnya: surat keterangan waris dari Balai Harta Peninggalan.

d. Surat Edaran Departemen Dalam Negeri Direktorat Jenderal Agraria Tanggal 20 Desember 1969 Nomor Dpt/12/63/12/69 tentang Surat Keterangan Warisan dan Pembuktian Kewarganegaraan. Dalam isi surat ini disebutkan bahwa untuk golongan keturunan Tionghoa, surat keterangan waris dibuat oleh Notaris. Disebutkan pula dalam isi surat ini bahwa penunjukan pejabat yang berwenang untuk membuat surat keterangan waris bersumber pada golongan-golongan penduduk pada alam kolonial (tidak lain adalah ketentuan dalam Pasal 131 dan 163 Indische Staatregeling) dan memang belum ada suatu peraturan tertentu yang mengatur siapa yang berwenang untuk membuat surat keterangan waris. Ketentuan pembagian golongan penduduk memang masih berlaku pada saat diberlakukannya Surat Edaran Departemen Dalam Negeri Direktorat Jenderal Agraria Nomor Dpt/12/63/12/69, hal tersebut dikarenakan adanya Pasal II Undang Undang Dasar 1945 bagian Aturan Peralihan, menyebutlan bahwa segala badan negara dan peraturan yang ada masih langsung berlaku, selama belum diadakan yang baru menurut Undang Undang Dasar ini.

Berdasarkan ketentuan tersebut di atas, dapat diketahui bahwa, pembuatan surat keterangan ahli waris bagi masing-masing golongan penduduk, berlaku ketentuan sebagai berikut:

a. bagi Warga Negara Indonesia penduduk asli, maka surat keterangan ahli waris dibuat oleh para ahli waris dengan disaksikan oleh 2 (dua) orang saksi dan Kepala Desa/Kelurahan, dan diketahui oleh Camat tempat tinggal pewaris pada waktu meninggal.

b. bagi Warga Negara Indonesia keturunan Tionghoa, maka akta keterangan hak mewaris (surat keterangan ahli waris) dibuat oleh Notaris.

c. bagi Warga Negara Indonesia keturunan Timur Asing lainnya, maka surat ahli keterangan waris oleh Balai Harta Peninggalan. 
d. Setelah berlakunya Undang-undang Nomor 7 Tahun 1989 tentang Peradilan Agama sebagaimana telah diubah dengan Undang-undang Nomor 3 Tahun 2006 tentang Perubahan atas Undang-undang Nomor 7 Tahun 1989 tentang Peradilan Agama, maka berdasarkan Pasal 49 huruf b ditentukan bahwa bagi penduduk Indonesia yang beragama Islam, dalam mengeluarkan surat keterangan ahli waris, pihak yang berwenang mengeluarkan penetapan mengenai pembagian harta peninggalan seorang pewaris yang beragama Islam adalah Pengadilan Agama.

\section{Kekuatan hukum surat keterangan ahli waris bagi anak luar kawin}

Surat keterangan waris tidak termasuk sebagai hukum waris secara materil, tetapi merupakan bagian dari hukum acara perdata (hukum formil) yang terkait dengan masalah pembuktian tentang pihak-pihak yang berhak untuk mendapatkan harta warisan, dan dalam pelaksanaannya antara hukum waris sebagai bagian hukum materil dengan surat keterangan ahli waris sebagai bagian dari hukum formil, tidak dapat dipisahkan.

Memperhatikan ketentuan yang terdapat dalam Kitab Undang-undang Hukum Perdata (KUH Perdata), maka secara materil untuk dapat menjadi seorang ahli waris telah ditetapkan syarat-syarat sebagai berikut:

a. Berdasarkan Pasal $832 \mathrm{KUH}$ Perdata ditentukan bahwa untuk dapat menjadi ahli waris harus memiliki hubungan darah baik sah atau luar kawin.

b. Berdasarkan Pasal 874 KUH Perdata, dimungkinkan menjadi ahli waris melalui pemberian melalui surat wasiat.

c. Berdasarkan Pasal $836 \mathrm{KUH}$ Perdata, maka ahli waris harus sudah ada pada saat pewaris meninggal dunia, tetapi ada pengecualian sebagaimana dimaksud oleh Pasal 2 KUH Perdata yang menyebutkan bahwa anak yang ada dalam kandungan seorang perempuan dianggap sebagai telah dilahirkan, bilamana kepentingan si anak menghendakinya.

Ketentuan yang terdapat Pasal 832 KUH Perdata telah memperjelas kedudukan masing-masing ahli waris harus didasari oleh suatu hubungan darah baik sah maupun luar kawin. Dalam hal ini, perlu diidentifikasi lebih lanjut tentang kedudukan anak-anak pewaris sebagai ahli waris, mengingat dalam suatu pewarisan menurut KUH Perdata dikenal anak luar kawin, baik yang diakui secara sah maupun tidak, sedangkan KUH Perdata tidak menjelaskan lebih lanjut tentang maksud anak luar kawin. Dalam Pasal 250 KUH Perdata, hanya ada disebutkan pengertian anak sah, yaitu setiap anak yang dilahirkan dan atau dibuahkan dari suatu perkawinan yang sah, dan oleh sebab itu dapat dikatakan bahwa yang disebut dengan anak luar kawin adalah setiap anak yang dilahirkan di luar perkawinan yang sah. Menurut Tan Thong Kie (2011: 18), dikatakan bahwa: "keturunan (afstamming) adalah hubungan darah antara anak-anak dengan orang tuanya. undang-undang mengenal anak-anak 
sah dan anak-anak tidak sah (wettige en onwettige kinderen), dan yang terakhir ini juga diberi nama anak luar nikah (natuurlijkc kinderen) atau diterjemahkan sebagai anak-anak alam".

Terkait dengan anak tidak sah atau dalam pengertian anak luar kawin, maka perlu pula diperhatikan ketentuan yang terdapat dalam Pasal 42 UU No. 1 Tahun 1974, yang menyebutkan bahwa anak yang sah adalah anak yang dilahirkan dalam atau sebagai akibat perkawinan yang sah. Sama hal nya dengan KUH Perdata, maka dalam UU No. 1 Tahun 1974 juga tidak ada dijelaskan tentang anak tidak sah, tetapi dalam Pasal 43 ayat (1) ditegaskan bahwa anak yang dilahirkan di luar perkawinan hanya mempunyai hubungan perdata dengan ibunya dan keluarga ibunya.

Hukum di Indonesia jelas membedakan antara keturunan (anak) yang sah dan keturunan (anak) yang tidak sah. Anak sah didasarkan pada perkawinan yang sah, dalam arti, bahwa yang satu adalah keturunan yang lain berdasarkan kelahiran atau sebagai akibat perkawinan yang sah, anak-anak yang demikian disebut anak sah (Satrio, 1992: 5), sedangkan anak tidak sah adalah keturunan yang tidak didasarkan atas suatu perkawinan yang sah, yang lazim disebut orang sebagai anak luar kawin.

Berdasarkan ketentuan yang terdapat dalam UU No. 1 Tahun 1974 dan KHI, anak yang sah adalah yang dilahirkan dari perkawinan yang sah, sedangkan perkawinan yang sah adalah perkawinan yang sesuai dengan agama dan kepercayaannya dan dicatat oleh lembaga negara (Kantor Urusan Agama atau Kantor Catatan Sipil). Anak yang dilahirkan dari perkawinan tidak dicatatkan (walaupun memenuhi ketentuan agama), dianggap sebagai anak luar kawin, maka tidak mendapatkan hak-hak seperti halnya anak-anak yang dilahirkan dari perkawinan yang sah menurut undang-undang. Hak-hak yang tidak didapat itu adalah masalah keperdataan yang berkaitan dengan status dan hubungan hukum dengan bapak biologisnya.

Stigma anak tidak sah dan anak luar kawin dalam bahasa hukum di Indonesia bagi anak yang dilahirkan dari hubungan luar kawin atau perkawinan yang tidak sah telah membenturkan hubungan hukum agama dengan hukum negara dalam hal pengakuan anak yang dilahirkan dari perkawinan yang tidak dicatatkan. Anak-anak yang dilahirkan dari perkawinan yang tidak dicatatkan dianggap sebagai anak luar kawin (dianggap tidak sah) oleh negara, sehingga anak hanya mempunyai hubungan perdata dengan ibu dan keluarganya, sedangkan hubungan perdata dengan bapaknya tidak ada.

Ketentuan hukum sebagaimana disebutkan di atas dirasakan sangat tidak adil bagi anak, karena sesungguhnya anak tidak pernah menginginkan dilahirkan secara tidak sah, sebagai akibat dari perkawinan orang tuanya tidak dicatatkan. Tepat kiranya jika Mahkamah Konstitusi melalui Putusan Nomor 46/PUU-VIII/2010, telah memutuskan bahwa anak mempunyai hubungan perdata dengan bapak 
biologisnya, jika dapat dibuktikan melalui ilmu pengetahuan dan teknologi atau bukti lainnya. Atas dasar Putusan Mahkamah Konstitusi ini, diasumsikan timbul konsekuensi yuridis bahwa anak tidak sah (dalam pengertian anak yang lahir dari perkawinan tidak tercatat), tetap berhak untuk mendapat warisan yang ditinggalkan oleh bapak biologisnya, tetapi permasalahan ini belum selesai, karena jika seseorang meninggal dunia dan ada harta yang ditinggal, maka dalam perspektif hukum acara, para ahli waris yang berhak harus dibuktikan melalui penerbitan surat keterangan ahli waris.

Mencermati ketentuan yang terkait dengan pembuatan surat keterangan ahli waris sebagaimana yang dijelaskan sebelumnya, maka tertutup kemungkinan bagi anak luar kawin dari perkawinan tidak tercatat untuk dimuat namanya dalam surat keterangan ahli waris. Alasannya bahwa dalam proses pembuatan surat keterangan waris selalu didasarkan pada bukti tertulis yang menerangkan bahwa antara pewaris (dalam hal ini pewaris adalah bapak) dengan para ahli waris (anakanaknya) terdapat hubungan hukum yang diatur dalam hukum perkawinan, misalnya melalui Kartu Keluarga atau melalui Akta Kelahiran yang diterbitkan oleh pemerintah setempat, sementara bagi anak luar kawin, dalam Akta Kelahiran saja hanya disebutkan nama ibunya.

Peraturan perundang-undangan yang terkait proses pembuatan surat keterangan ahli waris juga tidak ada mengatur bahwa anak luar kawin dapat dimuat namanya dalam surat keterangan ahli waris tersebut. Sekali lagi dapat dikatakan bahwa dalam proses pembuatan surat keterangan ahli waris, masih terdapat problematika yuridis yang harus dicarikan solusinya oleh pemerintah. Hal ini bertujuan untuk memberikan perlindungan hukum kepada anak luar kawin dari perkawinan tidak tercatat, karena sesuai dengan Alinea Keempat Pembukaan UUD 1945, salah satu tujuan politik hukum Negara Republik Indonesia adalah untuk melindungi segenap bangsa Indonesia, dan sesuai pendapat Philipus M. Hadjon yang dijelaskan sebelumnya, bahwa prinsip perlindungan hukum di Indonesia adalah prinsip pengakuan dan perlindungan terhadap harkat dan martabat manusia yang bersumber pada Pancasila. Demi tercapainya perlindungan hukum dimaksud, maka harus dilakukan melalui pembaharuan peraturan perundang-undangan, yang pada akhirnya bermuara pada kepastian hukum hak waris anak luar kawin dari perkawinan tidak tercatat, karena untuk menciptakan kepastian hukum, harus ada aturan hukum yang jelas dan konsisten. Pencapaian tujuan hukum yang demikian ini memerlukan suatu perangkat aturan hukum yang jelas dan memadai, sesuai dengan aturan norma-norma yang terdapat dalam masyarakat Indonesia.

Berdasarkan ketiga sistem hukum waris yang berlaku di Indonesia, maka masing-masing menentukan bahwa suatu proses pewarisan terjadi karena adanya kematian dan dengan sendirinya karena kematian pula harta waris pewaris beralih kepada ahli waris. Sebagaimana yang terdapat dalam KUH Perdata, ada 2 (dua) aturan, yaitu: 
a. Pasal $830 \mathrm{KUH}$ Perdata, pewarisan hanya berlangsung karena kematian; dan

b. Pasal $833 \mathrm{KUH}$ Perdata, sekalian ahli waris dengan sendirinya karena hukum memperoleh hak milik atas segala barang, segala hak dan segala piutang si yang meninggal.

Dalam perspektif hukum waris Islam, terdapat prinsip kewarisan hanya karena kematian dan prinsip ijbāri. Prinsip kewarisan hanya karena kematian, bahwa peralihan harta seseorang kepada orang lain dengan sebutan kewarisan berlaku setelah yang mempunyai harta tersebut meninggal dunia. Prinsip ijbāri, maksudnya adalah peralihan harta seseorang yang telah meninggal dunia kepada yang masih hidup berlaku dengan sendirinya. Demikian pula pada hukum waris adat, yang prinsip utama dari sistem pewarisannya adalah harus ada yang meninggal dunia. Soerjono Soekanto (1983: 262), mengatakan bahwa, "bila seorang meninggal, maka ahli waris adalah anak-anak dari si peninggal harta". Selanjutnya Soerjono Soekanto (1983: 270), memberi penegasan pendapat Soepomo yang mengatakan bahwa proses peralihan harta dapat dimulai sejak pewaris masih hidup, dan pengalihan harta dalam keluarga sendiri hanya bersifat sementara, itu pun biasanya hanya terjadi pada keluarga dengan sistem patrilineal atau parental untuk anak laki-laki yang sudah dewasa, tetapi tetap tidak merupakan peristiwa pemberian harta warisan.

Dapat dimaklumi bahwa walaupun harta waris berpindah dengan sendiri-nya dari pewaris kepada ahli waris ketika pewaris meninggal dunia, tetapi masih dibutuhkan suatu instrumen yang dapat digunakan sebagai suatu alat bukti yang dapat menunjukan bahwa seseorang adalah benar orang yang berhak atas suatu harta waris, karena seperti misalnya harta waris yang berupa tanah memerlukan proses pendaftaran hak, apabila terjadi peralihan hak yang disebabkan oleh pewarisan. Begitu pula harta waris yang tersimpan di suatu bank juga memerlukan proses pencairan dana ataupun pindah buku dari rekening pewaris kepada ahli waris, dan untuk membuktikan seseorang memang benar berhak atas harta waris, yang membutuhkan proses peralihan pada instansi-intansi tertentu dibutuhkan adanya surat keterangan ahli waris, dan tanpa surat keterangan seperti ini, maka seseorang belum dapat dikatakan adalah benar sebagai ahli waris.

Dalam perspektif hukum perdata, alat bukti diatur dalam Pasal 164 Herzien Inlandsch Reglement (HIR), yang terdiri dari bukti tulisan (surat), bukti dengan saksi, persangkaan, pengakuan dan sumpah (Retnowulan Sutanto, 1997: 61). Berdasarkan Pasal 165 HIR disebutkan pula bahwa surat (akta) yang sah, ialah suatu surat yang diperbuat demikian oleh atau di hadapan pegawai umum yang berkuasa untuk membuatnya, menjadi bukti yang cukup bagi kedua belah pihak dan ahli warisnya dan sekalian orang yang mendapatkan hak daripadanya tentang segala hal yang disebut di dalam surat itu dan juga tentang yang ada dalam surat itu 
sebagai pemberitahuan sahnya, dalam hal terakhir ini hanya jika yang diberitahukan itu berhubungan langsung dengan perihal pada surat (akta) itu.

Subekti (1978: 27) mengatakan bahwa: “yang dimaksud dalam Pasal 165 HIR tersebut adalah akta otentik yang merupakan alat bukti sempurna. Akta otentik memberikan di antara para pihak termasuk para ahli warisnya atau orang yang mendapat hak dari para pihak itu suatu bukti yang sempurna tentang hal yang dimuat di dalamnya", sedangkan Habib Adjie (2009: 62) menjelaskan bahwa: "kekuatan pembuktian sempurna yang terdapat dalam suatu akta otentik merupakan perpaduan dari beberapa kekuatan pembuktian dan persyaratan yang terdapat padanya. Dalam suatu akta otentik harus memenuhi kekuatan pembuktian lahir, formil, dan materil".

Kehadiran ataupun kesaksian seorang pejabat umum terhadap suatu alat bukti sehingga dapat menambah kekuatan pembuktiannya, dapat dikategorikan dalam unsur formal dari suatu akta, yaitu mengenai formalitas akta, mengenai kebenaran apa yang dilihat, disaksikan dan didengar oleh seorang pejabat, juga mengenai kebenaran pernyataan ataupun keterangan para pihak yang disampaikan di hadapan pejabat yang berwenang. Dalam kaitan ini, maka Kepala Desa/Lurah dan Camat adalah pejabat tata usaha negara yang bertugas untuk melaksanakan urusan pemerintahan dengan cara mengeluarkan keputusan-keputusan tata usaha negara, sedangkan surat keterangan ahli waris sebagai suatu instrumen yang dapat membuktikan apakah seseorang adalah benar-benar ahli waris, merupakan suatu alat bukti dalam ranah bidang hukum perdata. Tentunya tidaklah tepat apabila Kepala Desa/Lurah dan Camat dinilai dapat memberikan unsur formal terhadap surat keterangan ahli waris, apabila tidak memiliki kewenangan yang dimaksud yang diatur dalam suatu peraturan perundang-undangan.

Demikian pula halnya jika surat keterangan ahli waris yang dikeluarkan oleh Balai Harta Peninggalan menimbulkan suatu permasalahan, kemana surat keterangan waris yang merupakan penetapan dari Balai Harta Peninggalan ini harus dipermasalahkan ataupun dibatalkan, apakah ke lingkungan Peradilan Tata Usaha Negara karena merupakan penetapan tertulis yang dikeluarkan oleh Badan atau Pejabat Tata Usaha Negara, atau ke dalam lingkungan peradilan umum karena merupakan suatu alat bukti dalam ranah bidang hukum perdata.

Melihat kenyataan yuridis seperti dijelaskan di atas, maka masyarakat akan menghadapi ketidakpastian hukum ketika surat keterangan ahli waris bermasalah. Tidak mungkin pelaksanaan hukum dapat menjamin kepastian hukum, apabila dari sisi substansi (orientasi) hukum juga belum ada jaminan kepastian hukum, padahal menurut Reinhold Zippelius (dalam Suseno, 2001: 79-80) sebagaimana disebutkan sebelumnya bahwa kepastian hukum harus dilihat dari 2 (dua) sisi, yaitu kepastian dalam pelaksanaannya, dan kepastian orientasi, maksudnya bahwa hukum itu harus jelas, sehingga masyarakat dan hakim dapat berpedoman padanya, yang berarti 
bahwa setiap istilah dalam hukum harus dirumuskan dengan terang dan tegas sehingga tidak ada keragu-raguan tentang tindakan apa yang dimaksud.

\section{KESIMPULAN}

Berdasarkan hasil penelitian dan analisis, dapat disimpulkan bahwa aturan hukum terkait surat keterangan ahli waris bagi anak luar kawin dari perkawinan tidak tercatat belum dapat menjamin perlindungan hukum dan kepastian hukum, karena pembuatan surat keterangan ahli waris yan g isinya memuat nama anak luar kawin dari perkawinan tidak tercatat, belum dapat dilakukan, berhubung belum ada peraturan perundang-undangan yang menentukan bahwa anak luar kawin dari perkawinan tidak tercatat dapat disebut dalam surat keterangan tersebut, sehingga surat keterangan waris yang memuat nama anak luar kawin dari perkawinan tidak tercatat, tidak mempunyai kekuatan hukum, khususnya dalam proses pembuktian.

Mengingat bahwa terkait dengan hak waris anak luar kawin dan surat keterangan ahli waris bagi anak luar kawin dari perkawinan tidak tercatat masih menimbulkan problematika yuridis, maka perlu disarankan, bahwa pemerintah hendaknya mengeluarkan peraturan perundang-undangan yang terkait dengan kedudukan dan penetapan hak waris anak yang lahir dari perkawinan tidak tercatat dan hendaknya segera menerbitkan peraturan perundang-undangan yang tegas dan jelas untuk mengatur tentang pembuatan surat keterangan ahli waris, baik terhadap perkawinan yang sah secara agama dan tercatat, maupun terhadap perkawinan yang sah secara agama tetapi tidak tercatat.

\section{DAFTAR PUSTAKA}

a. Buku/Kamus:

Abdurrahman dan Ridwan Syahrani (1986). Masalah-masalah Hukum Perkawinan di Indonesia. Bandung: Alumni.

Adjie, Habib (2009). Sekilas Dunia Notaris dan PPAT Indonesia (Kumpulan Tulisan). Bandung: Mandar Maju.

Anshary, M. (2010). Hukum Perkawinan di Indonesia Masalah-masalah Krusial. Yogyakarta: Pustaka Pelajar.

Anshari, M. (2014). Kedudukan Anak dalam Perspektif Hukum Islam dan Hukum Nasional. Bandung: CV. Mandar Maju.

BPHN (1997/1998). Penyusunan Kamus Hukum Umum Bahasa Belanda-Bahasa Indonesia. Jakarta: BPHN-Departemen Kehakiman dan HAM RI.

Darmodiharjo, Darji dan Shidarta (1996). Penjabaran Nilai-nilai Pancasila dalam Sistem Hukum Indonesia. Jakarta: Rajawali Pers.

Hadjon, Philipus M. (1987) Perlindungan Hukum bagi Rakyat Indonesia. Surabaya: Bina Ilmu.

Ibrahim, Johny (2006). Teori dan Metodologi Penelitian Hukum Normatif. Cetakan Kedua. Malang: Bayumedia Publishing.

Kie, Tan Thong (2011). Studi Notariat Serba Serbi Praktik Notaris. Jakarta: Ichtiar Baru Van Hoeve. 
Lumban Tobing, G.H.S. (1999). Peraturan Jabatan Notaris-notaris Reglement. Jakarta: Erlangga.

Mertokusumo, Sudikno (1993). Bab-bab tentang Penemuan Hukum. Bandung: Citra Aditya Bakti.

Otto, Jan Michiel (2003). "Reele Rechtszekerheidin Ontwikkelingslanden", Kepastian Hukum yang Nyata di Negara Berkembang. Penerjemah Tristam Moeliono. Cetakan Pertama. Jakarta: Komisi Hukum Nasional Republik Indonesia (KHNRI).

Pusat Bahasa Departemen Pendidikan Nasional (2002). Kamus Besar Bahasa Indonesia. Jakarta: Balai Pustaka.

Rahardjo, Satjipto (1983). Permasalahan Hukum di Indonesia. Bandung: Alumni.

Ramulyo, Mohd. Idris (1996). Hukum Perkawinan Islam, Suatu Analisis dari Undangundang Nomor 1 Tahun 1974 dan Kompilasi Hukum Islam. Jakarta: PT. Bumi Aksara.

Riyanto, Astim (2002). Filsafat Hukum. Bandung: Yapemdo.

Sarwanto, Ahmad (2013). Perkawinan Tidak Dicatatkan. Jakarta: Cipta Karya.

Satrio, J. (1992). Hukum Waris. Bandung: Alumni.

Setiono (2004). Rule of Law (Supremasi Hukum). Surakarta: Magister Ilmu Hukum Program Pascasarjana Universitas Sebelas Maret.

Soekanto Soerjono dan Sri Mamudji (2003). Penelitian Hukum Normatif, Suatu Tinjauan Singkat. Cetakan Keenam. Jakarta: RadaGrafindo Persada.

Soekanto, Soerjono (1983). Hukum Adat Indonesia. Jakarta: RajaGrafindo Persada.

Soekanto, Soerjono (1986). Pengantar Penelitian Hukum. Cetakan Ketiga. Jakarta: UIPress.

Soekanto, Soerjono (1998). Metodologi Research. Yogyakarta: Andi Offset.

Subekti, R. (1978). Hukum Pembuktian. Jakarta: Pradnya Paramita.

Suseno, Franz Magnis (2001). Etika Politik. Jakarta: Gramedia Pustaka Utama.

Sutanto, Retnowulan (1997) Hukum Acara Perdata dalam Teori dan Praktik. Bandung: Mandar Maju.

Witanto, D.Y. (2012). Hukum Keluarga Hak dan Kedudukan Anak Luar Kawin Pasca Keluarnya Putusan MK tentang Uji Materiil UU Perkawinan. Jakarta: Prestasi Pustaka.

\section{b. Disertasi:}

Erwinsyahbana, Tengku (2012). "Kajian atas Kepastian Hukum Perkawinan Antar Agama Dikaitkan dengan Sistem Hukum Perkawinan Indonesia dalam Perspektif Pembangunan Hukum Keluarga Nasional”. Disertasi. Bandung: Program Studi Doktor Ilmu Hukum Fakultas Hukum Pascasarjana Universitas Padjadjaran. 


\section{c. Jurnal}

Arifin, Muhamad (2017). Kedudukan Anak Luar Kawin: Analisis Putusan Mahkamah Konstitusi No. 46/PUUVIII/2010 tentang Uji Materi terhadap Pasal 43 Ayat 1 UU No. 1 Tahun 1974 tentang Perkawinan. Ahkam, 5(1).

Muhammadi, Fauzan (2017). Legalitas Nikah Sirri Ditinjau dari Kaidah Fikih. De Jure: Jurnal Hukum dan Syari'ah, 9(1).

Hairi, Prianter Jaya (2012). "Status Keperdataan Anak Diluar Nikah Pasca-Putusan Mahkamah Konstitusi Nomor 46/PUU-VIII/2010”. Info Singkat Hukum. 4(6).

Ibrahim, Nurbaeti dan Yunardi (2012). "Tinjauan Yuridis Hak Anak dari Perkawinan Siri Pasca Putusan Mahkamah Konstitusi Nomor 46/PUU-VIII/2010". Legalitas, 3(2).

Khisni, A. (2014). “Kontroversi Putusan Mahkamah Konstitusi tentang Perkawinan di Bawah Tangan (Studi tentang Hukum Perkawinan antara Normatif dengan Empiris untuk Menggali Maqashid-AL-Syari'ah dalam Upaya Mewujudkan Fikih Indonesia)". Jurnal Pembaharuan Hukum, 1(3).

Rahmi, Atikah dan Sakdul (2016). "Fungsi Pencatatan Perkawinan Dikaitkan dengan Upaya Perlindungan Hukum terhadap Anak Setelah Putusan Mahkamah Konstitusi Nomor: 46/PUU-VIII/2010". De Lega Lata, 1(2).

\section{d. Internet:}

Ashiddiqie, Jimly. "Keadilan, Kepastian Hukum dan Keteraturan". http://www. suarakarya-online.com. diakses tanggal 12 Maret 2015.

\section{e. Peraturan Perundang-undangan:}

Republik Indonesia, Undang Undang Dasar Negara Tahun 1945

Republik Indonesia, Undang-undang Nomor 1 Tahun 1974 tentang Perkawinan

Republik Indonesia, Undang-undang Nomor 3 Tahun 2006 tentang Perubahan atas Undang-undang Republik Indonesia Nomor 7 Tahun 1989 tentang Peradilan Agama

Republik Indonesia, Undang-undang Nomor 23 Tahun 2006 tentang Administrasi Kependudukan

Republik Indonesia, Undang-undang Nomor 2 Tahun 2014 tentang Perubahan Atas Undang-undang Republik Indonesia Nomor 30 Tahun 2004 tentang Jabatan Notaris

Republik Indonesia, Peraturan Pemerintah Nomor 24 Tahun 1997 tentang Pendaftaran Tanah

Republik Indonesia, Peraturan Pemerintah Nomor 37 Tahun 2007 tentang pelaksanaan Undang-undang Nomor 23 Tahun 2006 tentang Administrasi kependudukan

Peraturan Presiden Nomor 25 Tahun 2008 tentang Persyaratan dan Tata Cara Pendaftaran Penduduk dan Pencatatan Sipil

Republik Indonesia, Instruksi Presiden Nomor 1 Tahun 1991 tentang Kompilasi Hukum Islam 
Republik Indonesia, Peraturan Menteri Negara Agraria/Kepala Badan Pertanahan Nasional Nomor 3 Tahun 1997 tentang Pelaksanaan Peraturan Pemerintah Nomor 24 Tahun 1997 tentang Pendaftaran Tanah

Republik Indonesia, Surat Edaran Departemen Dalam Negeri Direktorat Jenderal Agraria Tanggal 20 Desember 1969 Nomor Dpt/12/63/12/69 tentang Surat Keterangan Warisan dan Pembuktian Kewarganegaraan.

Republik Indonesia, Putusan Mahkamah Konstitusi Indonesia Nomor 46/PUUVII/2010. 